\title{
ECOLOGICAL, ECONOMIC AND SOCIAL ISSUES OF IMPLEMENTING CARBON DIOXIDE SEQUESTRATION TECHNOLOGIES IN THE OIL AND GAS INDUSTRY IN RUSSIA
}

\author{
Alexey Cherepovitsyn ${ }^{1}$, Alina Ilinova ${ }^{1}$ \\ 1 National Mineral Resources University (Mining University), Vasil'evsky Ostrov, 21 liniya 2, Saint-Petersburg, \\ Russia, 199106, e-mail: alekseicherepov@inbox.ru, iljinovaaa@mail.ru
}

Received: 2016.02 .10

Accepted: 2016.03.04

Published: 2016.04.01

\begin{abstract}
The objective of this paper is to define the main approaches to the implementation of carbon dioxide sequestration technologies in the oil and gas industry in Russia, and also to identify ecological, economic and social issues of their usage. Promotion of the technology of carbon dioxide $\left(\mathrm{CO}_{2}\right)$ sequestration by means of capturing and injecting it into underground reservoirs is a promising mechanism of reducing carbon dioxide concentration. Carbon capture and storage (CCS) technologies might be used to enhance oil recovery (EOR-CO $)_{2}$ and production by means of oil extraction and decreasing oil viscosity. Conceptual view of the potential of EOR-CO $\mathrm{C}_{2}$ technologies within the context of oil and gas industry sustainable development are presented. Incentives of the CCS projects implementation are identified. On the basis of the conducted research a number of scientific research and practical areas of the CCS technology development are presented.
\end{abstract}

Keywords: carbon dioxide, sequestration, carbon capture and storage, oil recovery, EOR-CO, technology, oil and gas, Russia.

\section{INTRODUCTION}

The key challenges of global energy sector, such as deterioration of reserves quality, the increasing importance of energy- and resourcesaving technologies, environmental restrictions, the adoption of unconventional raw hydrocarbon sources, economic and technological sanctions, require undertaking interest in a new conception of sustainable development for oil and gas industry (OGI). The model of modern OGI development should reflect the change in priorities and the switch to the conception based on innovations and resources, in which resources exploitation is based upon rational usage of mineral resources, energy costs optimization and more complete extraction of the hydrocarbons.

The paradigm of modern sustainable development of Russian OGI should be grounded upon innovations, which form a high-tech, rational, ecologically-balanced system of operation of oil and gas production, transportation and refinery enterprises [Cherepovitsyn 2009].

The principles of Russian OGI operation in the modern economic conditions may and should provide for a use of sets of organizational and technical, economic solutions targeted on the adoption and implementation of environmental and nature conservation related technologies. That makes it possible to use the options of greenhouse gas reduction that are widespread in the Western countries in order to ensure energy-efficient development and rational usage of natural resources.

Promotion of the technology of carbon dioxide sequestration by means of capturing and injecting it into the underground reservoirs is a promising mechanism of reducing carbon dioxide $\left(\mathrm{CO}_{2}\right)$ concentration. 


\section{MAIN APPROACHES TO THE IMPLEMENTATION OF CARBON CAPTURE AND STORAGE TECHNOLOGIES (CCS)}

By the estimates of the International Energy Agency (IEA), contribution of Carbon Capture and Sequestration (CCS) technologies to the worldwide emission reduction may reach 1.5 billion tons of $\mathrm{CO}_{2}$ a year by 2050 [Energy technology prospects. International Energy Agency 2011, WWF - The Energy Report 2011].

The proportion of the CCS technologies in reduction of the global emission is estimated to be from 20 to 28 percent, which indicates the prospects of development and vast adoption of such technologies [Energy technology prospects. International Energy Agency 2011, IEA - Energy Technology Perspectives 2010]. CCS technologies include the following technological processes: capturing, transportation and geological storage. Geological storage is linked with the possibility of injecting $\mathrm{CO}_{2}$ into saline formations (water-bearing strata), oil and gas fields, and coalbeds.

When injecting $\mathrm{CO}_{2}$ into the saline formations or oil and gas fields at depths exceeding 800 meters, one should consider mining and geological properties of the rock. The reservoirs should have high porosity in order to accumulate big amounts of carbon dioxide. The rocks inside are usually permeable, so that $\mathrm{CO}_{2}$ can penetrate into the underground reservoirs. At the same time, the storage reservoirs should be covered with impermeable overlying rocks in order to prevent surface leakages.

The coalbed storage might be implemented at shallow depths and is based on the $\mathrm{CO}_{2}$ adsorption by the coal. The technical practicability of such a technology to the great extent depends on the coalbed permeability.

The $\mathrm{CO}_{2}$ storage in oil and gas fields that are at the final production stage might be used to enhance oil recovery (EOR- $\mathrm{CO}_{2}$ ) and production by means of oil extraction and decreasing oil viscosity [Cherepovitsyn et al. 2013].

Enhancing oil recovery by the EOR-CO method may be characterized by the added value by usage of anthropogenic $\mathrm{CO}_{2}$, captured at power plants and industrial enterprises. Studies conducted by American experts showed that the worldwide potential of the EOR- $\mathrm{CO}_{2}$ is 340 billion barrels of technically recoverable oil resources and the capacitive potential of $\mathrm{CO}_{2}$ storage is
120,000 million tons. Large volumes of potential carbon dioxide storage in the oil reservoirs underline the interest in the EOR-CO 2 technologies [Beecy et al. 2004].

$\mathrm{CO}_{2}$ utilized in the underground reservoirs might be considered reduced greenhouse gas emissions. If there is a functioning carbon market, it is also possible to get some extra profits from the carbonic acid utilization.

It should be noted that the "Energy Strategy 2030 " forms a number of target indicators of oil production technological advancement, such as scaling up the implementation of industrial innovational technologies, enhanced oil recovery and intensified oil production. The gas, gas-water, thermal-gas, rheo-gas-chemical and thermal EOR methods were identified as priorities [Energy strategy of Russian Federation to 2030].

Experts estimate stimulating oil formation by gas, which includes injection of carbon dioxide, associated petroleum gas (APG), petroleum gas and flue gas to be one of the most effective and rational technological processes from the point of view of energy- and resource-saving and EOR.

\section{POSSIBILITIES OF THE EOR-CO TECHNOLOGIES IN THE CONTEXT OF OIL AND GAS INDUSTRY SUSTAINABLE DEVELOPMENT}

The concept of OGI sustainable development under the strategic vision of potential vast usage of the CCS technology is presented in Figure 1. In the OGI, the CCS technologies are related to injection of the anthropogenic $\mathrm{CO}_{2}$ into the oil formation in the first place.

The main problem of the EOR- $\mathrm{CO}_{2}$ usage is the high price of anthropogenic $\mathrm{CO}_{2}$. The CCS technologies, as mentioned above, are a combination of three processes: capturing, transportation and geological storage. These processes (stages) differ from each other considerably in terms of technical and technological practicability and have different experience of practical application. Currently, most of the CCS projects serve the demonstration purpose, therefore, there is no definite way to evaluate the costs of CCS technology usage. The implementation costs of the CCS technology depend on particular project, technological features of capturing industrial enterprises, mining and geological conditions of fields, distance of transportation etc. 


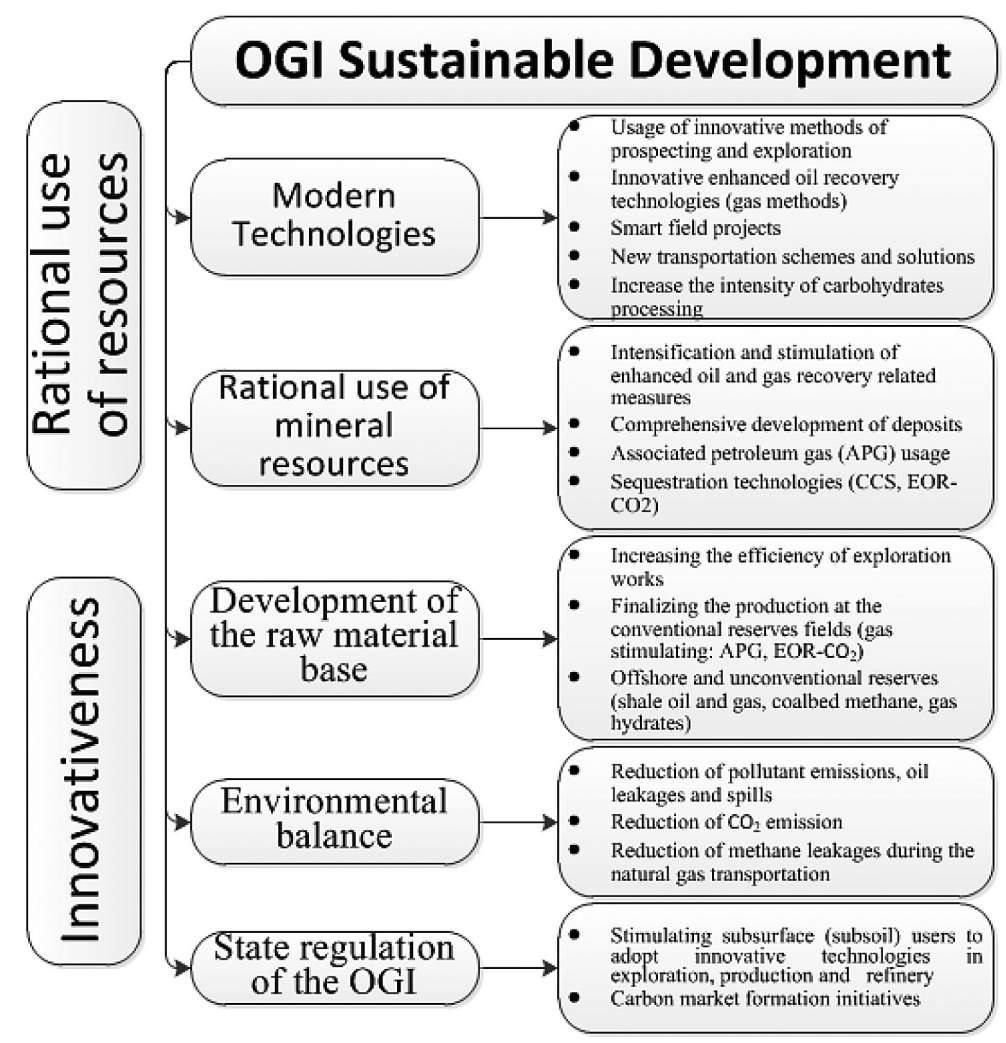

Figure 1. Conceptual view of EOR- $\mathrm{CO}_{2}$ technologies opportunities within the context of OGI sustainable development

According to the estimates from different experts, the cost of the CCS technologies varies from 1440 to 2136 rubles per ton of $\mathrm{CO}_{2}$. The cost of capturing is 1087-1392 rubles per ton of $\mathrm{CO}_{2}$, the transportation cost is 179-266 rubles per ton, and the storage cost in oil and gas reservoirs is about 174-478 rubles per ton. Thus, the cost of storage on the onshore fields accounts for around $12 \%$ of the overall that of the CCS technology, whereas the offshore accounts for around 22\% [Naucler et al. 2008, Toth et al. 2011].

Efficiency of the EOR-CO, technology usage also depends on the price of $\mathrm{CO}_{2}$ on the carbon market.

It has to be mentioned that the $\mathrm{CO}_{2}$ sequestration costs will differ at different stages of the technology development. Thus, at the demo stage (currently) projects are minor and focused on drawing attention of all the stakeholders to this technology in order to prove its efficiency and safety. At this stage, the cost of such projects remains rather high, especially at the $\mathrm{CO}_{2}$ capturing stage.

In the future, when CCS technologies enter the early commercial stage, on account of the economies of scale and trainings, the costs of adoption will decrease by $35 \%$. Later, by reach- ing of the commercial maturity stage the costs of CCS may decrease by extra $10-12 \%$.

Economic constraints for the domestic oil and gas industry on the EOR- $\mathrm{CO}_{2}$ technology usage under the possible creation of national carbon market or under the integration with the mechanisms of the European carbon credit market have to be identified. That would allow determining the price range and the critical pricing parameters of the CCS projects.

Injection of $\mathrm{CO}_{2}$ into the oil reservoirs is a complex process, the precise prognosis of the EOR- $\mathrm{CO}_{2}$ potential for Russian deposits may be determined by geological and economic modeling and detailed research of the potential reservoir capacity. The economic analysis of the EOR- $\mathrm{CO}_{2}$ schemes is a research, whose implementation entails additional difficulties related to the necessity of the improvement of technical and technological approaches, including the selection and usage of oil production equipment, taking specific capital and operating costs into account, evaluation of geological and investment risks.

The majority of Russian oil and gas fields (Western Siberia) are located in the areas that are remoted from the main industrial $\mathrm{CO}_{2}$ emission sources. The old oil and gas production ar- 
eas, such as Tatarstan and Bashkiria, the Northwestern region (including Kaliningrad oblast) are the most suitable for the EOR-CO ${ }_{2}$ methods usage. It is important to evaluate the geological and technical potential of the EOR- $\mathrm{CO}_{2}$ technology, the $\mathrm{CO}_{2}$ storage for the old oil production areas in the first place.

Reasonability of the effective and stimulating state policy for the large-scale CCS projects adoption is conditional on the demo stage and high capital intensity of such technologies, as wells as the uncertainty about the future world carbon market development. Therefore, incentives and the support of OGI companies' strategic initiatives in the resource-saving and environmental areas, one of which is the implementation of CCS projects, are necessary.

The typology of instruments of stimulating the CCS technology promotion has been developed in the paper. It is based on the principles of innovational resource-saving and resource-effective development of economic sectors in general and the OGI in particular (Figure 2) [European Commission 2013, Global CCS Institute 2009, Greenpeace 2008, IPCC - Renewable energy sources and climate change mitigation 2012, Rubin et al. 2005, Shapovalov et al. 2012, Van Egmond et al. 2012]. Besides organizational, administrative and economic incentives, it is suggested to pay great attention to the social aspects. Since the CCS technologies are innovative by themselves and are linked to the rational use of natural resources, it is instrumental to develop public awareness and image of socially responsible companies [Cherepovitsyn et al. 2011].

Furthermore, long-term storage of carbon dioxide in the geological reservoirs implies forming the mechanisms of monitoring the underground environment and evaluating the risks of potential release of $\mathrm{CO}_{2}$ to the surface. It is necessary to understand who will be monitoring and controlling the $\mathrm{CO}_{2}$ diffusion process in the underground formations over time.

There is also an interesting and important strategic problem of working out the mechanisms of interaction between the state, oil and gas companies, research institutes and environmental organizations to promote the CCS technologies, and EOR- $\mathrm{CO}_{2}$ in particular.

\section{CONCLUSIONS}

Thus, the CCS technology is a promising mechanism of carbon dioxide concentration reduction and one of the methods of enhancing oil recovery $\left(\mathrm{EOR}-\mathrm{CO}_{2}\right)$. On the basis of the conducted research a number of scientific research and practical areas of the CCS technology development are worth mentioning:

- Knowledge generation with purpose of formation of scientific problems and priorities of the CCS technology usage in Russian Federation,

- Formation of methodological approaches to evaluation and revaluation of geological reservoirs suitable for greenhouse gas conservation,
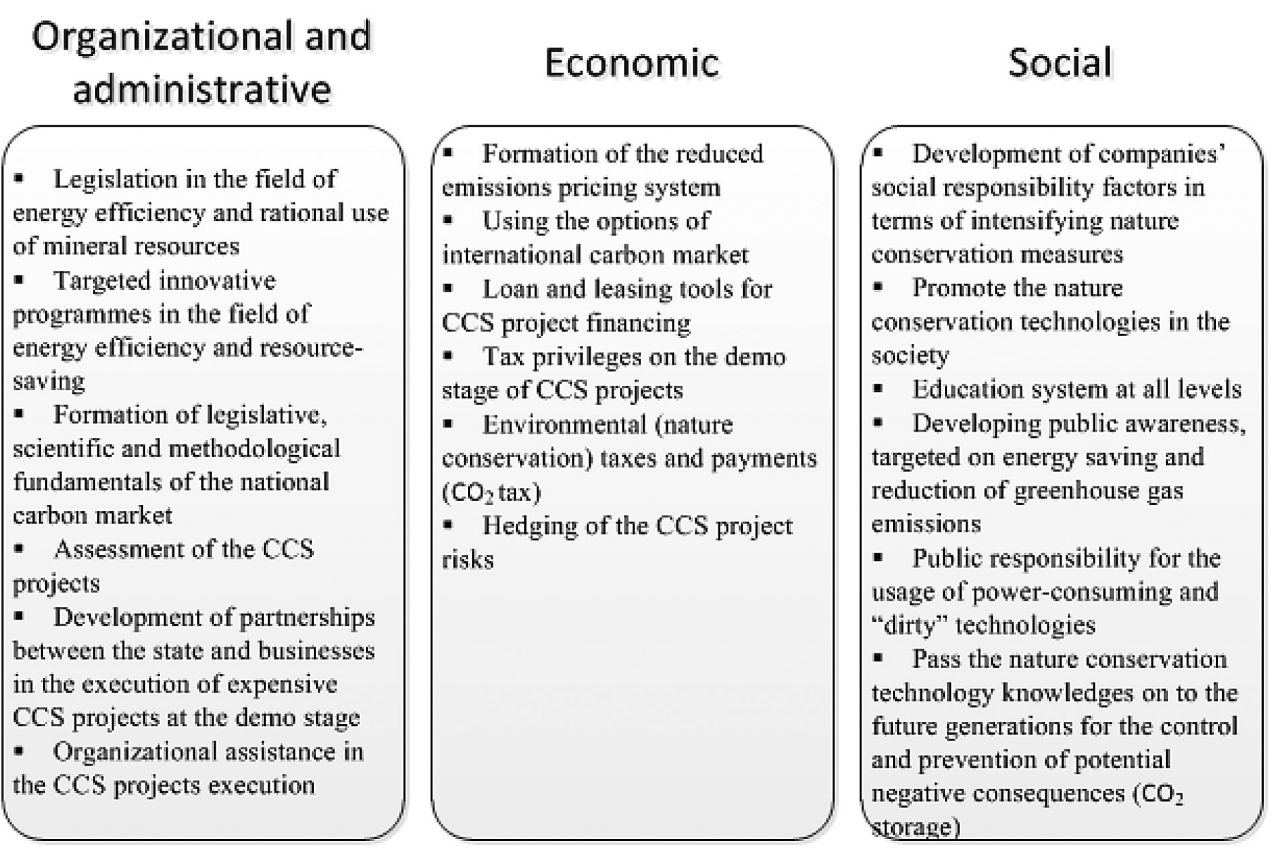

Figure 2. Incentives of the CCS projects execution 
- Building a system of geological and environmental maps, showing the places and potential of $\mathrm{CO}_{2}$ storage in geological structures, emission sources and the required infrastructure,

- Formation of conceptual framework of the national carbon market,

- Modeling marginal operating and capital costs of the CCS technology adoption, depending on the prognoses of carbon market development and technical advancement,

- Developing the mechanisms of interaction between the state and businesses in the CCS projects implementation,

- Developing the technique of geological, environmental and investment risks evaluation of the CCS projects.

\section{Acknowledgements}

The paper is based on research carried out with the financial support of the grant of the Russian Science Foundation (Project No. 14-3800009, The program-targeted management of the Russian Arctic zone development). Peter the Great St. Petersburg Polytechnic University.

\section{REFERENCES}

1. Beecy D., Kuuskraa V. 2004. Basin strategies for linking $\mathrm{CO}_{2}$ enhanced oil recovery and storage of $\mathrm{CO}_{2}$ emissions. 7th International Conference on Greenhouse Gas Control Technologies, Vancouver, Canada.

2. Cherepovitsyn A. 2009. The strategy of innovational development of the Russian Northwestern oil and gas industry. Thesis for the degree of Doctor of Economic Sciences, St. Petersburg

3. Cherepovitsyn A., Ilinsky A. 2011. Geological disposal of carbon dioxide and radioactive waste: A comparative assessment. Comparison of the Geological Disposal of Carbon Dioxide and Radioactive Waste in European Russia. International Atomic Energy Agency; Springer Dordrecht London Heidelberg New York, 513 p.

4. Cherepovitsyn A., Smirnova N., Ilinova A. 2013. On the storage of $\mathrm{CO}_{2}$ in geological formations: economic and social aspects. RISC: Resources, Information, Supply, Competition, 4, 171-174.

5. Energy strategy of Russian Federation to 2030. URL: http://www.energystrategy.ru/

6. Energy technology prospects. Strategies and sce- narios to 2050. International Energy Agency, 2011. URL: http://www.iea.org

7. European Commission - Reference Document on Best Available Techniques (BREF) in Mineral Oil \& Gas Refineries. Integrated Pollution Prevention and Control (IPPC), 2013, 730 p. URL: http://eippcb.jrc.ec.europa.eu/reference/BREF/ FD_REF_July_2013online.pdf

8. Global CCS Institute - Strategic Analysis of the Global Status of Carbon Capture and Storage. Report 3: Russia. 2009, 35 p. URL: http://cdn. globalccsinstitute.com/sites/default/files/publications/8622/strategic-analysis-global-status-ccscountry-study-russia.pdf

9. Greenpeace - False Hope - Why Carbon Capture and Storage Won't Save the Climate. Greenpeace International. 2008, 44 p. URL: http://www.greenpeace.org/usa/Global/usa/report/2008/5/falsehope-why-carbon-capture.pdf

10. IEA - Energy Technology Perspectives. Scenarios and Strategies to 2050. OECD/IEA, Paris. 2010. 710 p. URL: http://www.iea.org/publications/ freepublications/publication/etp2010.pdf

11. IPCC - Renewable energy sources and climate change mitigation. Special report, New York. 2012. 1088 p. URL: http://www.ipcc.ch/pdf/special-reports/srren/SRREN_Full_Report.pdf

12. Naucler T., Campbell W., Ruijs J. 2008. Carbon Capture \& Storage: Assessing the Economics. Report of McKinsey \& Company. 53 p. URL: http:// assets.wwf.ch/downloads/mckinsey2008.pdf

13. Rubin E.S. et al. 2005. Comparative Assessments of Fossil Fuel Power Plants with $\mathrm{CO}_{2}$ Capture and Storage. 7th International Conference on Greenhouse Gas Control Technologies (GHGT-7), T.1, Elsevier, 9 p. URL: http://repository.cmu.edu/cgi/ viewcontent.cgi? article $=1082 \&$ context $=$ epp

14. Shapovalov A., Davydova A. 2012. The climatic unconscious. Kommersant news paper. No. 232 (5017). URL: http://www.kommersant.ru/ doc/2084514

15. Toth F.L., Miketa A. 2011. Costs of the Geological Disposal of Carbon Dioxide and Radioactive Waste. Springer, 215-262.

16. Van Egmond S., Hekkert M.P. 2012. Argument Map for Carbon Capture and Storage. International Journal of Greenhouse Gas Control, 12 p. URL: http://dx.doi.org/10.1016/j.ijggc.2012.08.010

17. WWF - The Energy Report, 100\% Renewable Energy by 2050 . WWF/Ecofys/OMA, Gland, Switzerland. 2011. 256 p. URL: http://www.wwf.or.jp/ activities/lib/pdf_climate/green-energy/WWF_ EnergyVisionReport.pdf 